\title{
Inhalt
}

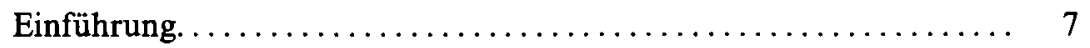

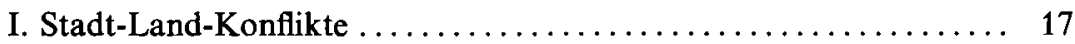

\section{Heiko Haumann}

Konfliktlagen und Konflikte zwischen Stadt und Land. Ein Vergleich von vier Regionen im östlichen Europa (1850 bis 1917) ......... 17

Klaus Tenfelde

Stadt und Land in Krisenzeiten. München und das Münchener Umland zwischen Revolution und Inflation 1918 bis $1923 \ldots \ldots \ldots \ldots \ldots \ldots, 37$

II. Soziale Räume - Stadtentwicklung - Städtebau ........... 59

Wolfgang Hardtwig

Soziale Räume und politische Herrschaft. Leistungsverwaltung, Stadterweiterung und Architektur in München 1870 bis 1914.......... 59

Heinz Reif

Stadtentwicklung und Viertelbildung im Ruhrgebiet: Oberhausen 1850 bis 1929

Stefan Fisch

Neue Aspekte der Münchener Stadtplanung zur Zeit Theodor Fischers (1893 bis 1901) im interurbanen Vergleich .................. 175

III. Quartierbildung und Mobilität ................... 193

Bruno Fritzsche

Mobilität im Stadtviertel: Zürich um $1870 \ldots \ldots \ldots \ldots \ldots \ldots \ldots \ldots . . \ldots 3$

Stephan Bleek

Das Stadtviertel als Sozialraum. Innerstädtische Mobilität in München 1890 bis 1933 ..................................... 217

IV. Kommunale Interessenpolitik und großstädtische Milieus ...... 235

Hermann Beckstein

München, der bayerische Städtetag und die städtischen Organisationsbestrebungen im letzten Viertel des 19. Jahrhunderts ............ 235

Sybille Leitner

Großstadtlust. Prostitution und Münchener Sittenpolizei um 1900 . . 261 
6 Inhalt

Die Autoren $\ldots \ldots \ldots \ldots \ldots \ldots \ldots \ldots \ldots \ldots \ldots \ldots \ldots \ldots \ldots \ldots$

Auswahlbibliographie $\ldots \ldots \ldots \ldots \ldots \ldots \ldots \ldots \ldots \ldots \ldots \ldots$

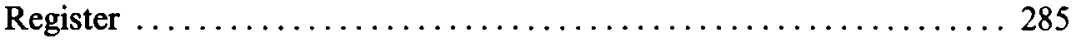

